\title{
PENGARUH MEDIA BUSY BOOK TERHADAP KEMAMPUAN PROBLEM SOLVING ANAK KELOMPOK A TAMAN KANAK-KANAK
}

\author{
I Wayan Suwatra ${ }^{1}$, Mutiara Magta $^{2}$, Chatarina Labore Aprillia Christiani $^{3}$ \\ 1,2,3 Universitas Pendidikan Ganesha \\ Singaraja, Indonesia \\ e-mail: Ignatiusiwayan.suwatra@undiksha.ac.id ${ }^{1}$, mutiara.magta@undiksha.ac.id ${ }^{2}$, \\ christianichatarina@gmail.com ${ }^{3}$
}

\begin{abstract}
Abstrak
Penelitian ini bertujuan untuk mengetahui perbedaan yang signifikan kemampuan problem solving antara anak yang distimulasi menggunakan media busy book dengan anak yang distimulasi dengan metode konvensional kelompok A Taman Kanak-kanak Gugus VII Kecamatan Buleleng tahun pelajaran 2018/2019. Jenis penelitian ini adalah quasi eksperimen dengan rancangan non-equivalen post test only control group design. Populasi penelitian ini adalah seluruh anak kelompok A Taman Kanak-kanak Gugus VII Kecamatan Buleleng tahun pelajaran 2018/2019, yang berjumlah 157 anak. Teknik pengambilan sampel dalam penelitian ini menggunakan teknik simple random sampling. Sampel penelitian ini adalah eksperimen pada kelompok A1 TK Santa Maria yang berjumlah 20 anak dan kontrol pada kelompok A1 di TK Lab Undiksha yang berjumlah 17 anak. Uji hipotesis menggunakan uji-t dengan taraf signifikan $5 \%$ dan dk $=2,03$ dengan demikian $t_{\text {hitung }}>t_{\text {tabel }}(15,882>2,03)$ maka $\mathrm{H}_{1}$ diterima dan $\mathrm{H}_{0}$ ditolak sehingga hasil penelitian menunjukan terdapat perbedaan yang signifikan kemampuan problem solving antara anak yang distimulasi menggunakan media busy book dengan anak yang distimulasi dengan metode konvensional kelompok A Gugus VII Kecamatan Buleleng tahun pelajaran 2018/2019. Dengan demikian media busy book berpengaruh terhadap kemampuan problem solving anak kelompok A Taman Kanak-kanak Gugus VII Kecamatan Buleleng tahun pelajaran 2018/2019.
\end{abstract}

Kata-kata kunci : Kemampuan Problem Solving, Busy Book, Media Pembelajaran, Anak Usia Dini

\begin{abstract}
The purpose of the study is to determine the significant differences in problem solving abilities between the children who were stimulated by busy book learning media and the children who were stimulated by conventional method in group A Taman Kanak-kanak Gugus VII Buleleng Sub-district in academic year 2018/2019. This study used a quasiexperimental with non-equivalent design with post-test only control group design. The population of this study was all children in group A Taman Kanak-kanak Gugus VII Buleleng Sub-district in academic year 2018/2019 which consisted of 157 children. The sampling technique used in this study was simple random sampling technique. There are 20 children in experiment group in group A1 at TK Santa Maria and 17 children in control in group A1 at TK Lab Undiksha. The hypothesis testing used t-test with a significant level of $5 \%$ and $\mathrm{dk}=2.03$, thus tcount> ttable $(15,882>2.03)$ then $\mathrm{H} 1$ was accepted and $\mathrm{HO}$ was rejected so the results showed that there were the significant differences in problem solving between the children who were stimulated by busy book learning media with the children who were stimulated by conventional method in group $A$ Gugus VII Buleleng Sub-district in academic year 2018/2019. Therefore, busy book learning media had effect with problem solving abilities of children in group A Taman Kanak-kanak Gugus VII Buleleng Sub-district in academic year 2018/2019.
\end{abstract}

Keywords: Problem Solving Ability, Busy Book, Learning Media, Young Children 


\section{Pendahuluan}

Undang-undang Nomor 20 Tahun 2003 tentang Sistem Pendidikan Nasional Pasal 1 angka 14 menyatakan bahwa Pendidikan Anak Usia Dini (PAUD) adalah suatu upaya pembinaan yang ditujukan kepada anak sejak lahir sampai dengan usia enam tahun yang dilakukan melalui pemberian rangsangan pendidikan untuk membantu pertumbuhan dan perkembangan jasmani dan rohani agar anak memiliki kesiapan dalam memasuki pendidikan lebih lanjut.

Pendidikan anak usia dini (PAUD) adalah jenjang pendidikan sebelum jenjang pendidikan dasar yang merupakan suatu upaya pembinaan yang ditujukan bagi anak sejak lahir sampai dengan usia enam tahun yang dilakukan melalui pemberian rangsangan pendidikan untuk membantu pertumbuhan dan perkembangan jasmani dan rohani agar anak memiliki kesiapan dalam memasuki pendidikan lebih lanjut, yang diselenggarakan pada jalur formal, nonformal, dan informal. Rentangan anak usia dini menurut Pasal 28 UU Sisdiknas No.20/2003 ayat 1 adalah 0-6 tahun. Sementara menurut kajian rumpun keilmuan PAUD dan penyelenggaraannya di beberapa negara, PAUD dilaksanakan sejak usia 0-8 tahun.

Pendidikan anak usia dini memegang peran penting dalam perkembangan anak karena pendidikan anak usia dini merupakan usia emas dalam meningkatkan perkembangan anak, pembentukan karakter, sikap, dan pengetahuan dasar anak terhadap lingkungannya. Pendidikan anak usia dini merupakan masa awal optimal dan salah satu aspek perkembangan yang dikembangkan adalah perkembangan kognitif khususnya dalam hal kemampuan pemecahan masalah.

Anak merupakan individu yang sangat unik yang memiliki karakteristik tersendiri sesuai dengan tahapan usianya. Oleh sebab itu, upaya pengembangan anak usia dini hendaknya dilakukan melalui belajar sambil bermain, karena bermain merupakan kegiatan yang amat sangat menyenangkan bagi anak. Melalui kegiatan bermain, anak akan banyak memperoleh kesempatan untuk bereksplorasi, berkreasi, dan berinteraksi dengan lingkungannya sehingga dapat mengembangkan kecerdasan anak. Hal tersebut diperkuat dengan pernyataan yang dikemukakan Sujiono (2010) bahwa melalui cara mengamati, meniru dan bereksperimen yang berlangsung secara berulang-ulang dan melibatkan seluruh potensi dan kecerdasan anak.

Berbagai interaksi dengan lingkungan dan aktivitas sehari-hari anak dalam membangun pengetahuannya sering kali dihadapkan pada masalah yang membutuhkan suatu cara pemecahan masalah yang melibatkan kemampuan kognitif. Sebagaimana telah diatur dalam Peraturan Menteri Pendidikan dan Kebudayaan Republik Indonesia Nomor 137 Tahun 2014, tentang Standar Nasional Pendidikan Anak Usia Dini salah satunya ialah aspek perkembangan kognitif yang harus dikembangkan meliputi. 1) Belajar dan pemecahan masalah; 2) Berpikir logis; dan 3) Berpikir simbolik, dalam lingkup berpikir logis terbagi lagi mencakup berbagai perbedaan, klasifikasi, pola, berinisiatif, berencana, dan mengenal sebab-akibat.

Kemampuan memecahkan masalah merupakan cara berpikir anak untuk memperoleh pengetahuan baru melalui pengalaman nyata. Perkembangan kemampuan pemecahan masalah pada anak dinyatakan dengan pertumbuhan dengan kemampuan merancang, mengingat dan mencari penyelesaian yang dihadapi. Berkaitan dengan hal tersebut, Piaget menyatakan bahwa perkembangan kemampuan pemecahan masalah dipengaruhi oleh faktor kematangan dan pengalaman untuk memahami masalah yang dihadapi.

Kemampuan memecahkan masalah adalah hal paling utama yang diperhatikan dalam diri anak. Hal ini dikarenakan ketika anak sedang melakukan proses bermain dan belajar, anak akan menemui permasalahan- permasalahan kecil yang perlu dipecahkan sendiri. Contoh ketika anak bermain membentuk rumah menggunakan balok, anak harus memecahkan masalah dengan menemukan cara menyusun balok-balok tersebut hingga benar dan menyerupai bentuk rumah. Kemampuan memecahkan masalah yang dimaksud ialah anak mampu menyelesaikan masalah atau tugas yang diberikan oleh guru. Hal ini dapat menjadi tolak ukur potensi dalam pencapaian perkembangan anak saat proses belajar mengejar berlangsung. Jika anak mampu memecahkan masalah atau meyelesaikan tugas sendiri maka 
perkembangan anak pada aspek kognitif dalam memecahkan masalah dapat dikatakan telah berkembang dengan baik.

Kemampuan pemecahan masalah (problem solving) adalah salah satu aspek keterampilan yang perlu dimiliki anak usia dini karena dalam kehidupan sehari-hari anak akan selalu dihadapkan pada berbagai permasalahan yang membutuhkan kemampuan pemecahan masalah. Kemampuan ini sangat penting dimiliki anak usia dini karena akan membangun kemampuan berfikir logis, kritis, dan sistematis. Maria (Setiasih, 2017) menyebutkan bahwa indikator keterampilan pemecahan masalah (problem solving) anak usia dini adalah keterampilan observasi, keterampilan mengumpulkan data dan informasi, keterampilan mengolah informasi, dan keterampilan mengkomunikasikan informasi.

Dalam Peraturan Menteri Pendidikan dan Kebudayaan Republik Indonesia Nomor 137 Tahun 2014 tentang Standar Nasional Pendidikan Anak Usia Dini dinyatakan bahwa standar kemampuan problem solving untuk anak usia 4-5 tahun meliputi 1) mengenal benda berdasarkan fungsi, 2) menggunakan benda-benda sebagai permainan simbolik, 3) mengenal konsep sederhana dalam kehidupan sehari-hari, 4) mengetahui konsep banyak dan sedikit, 5) mengkreasikan sesuatu sesuai dengan idenya sendiri yang terkait dengan berbagai pemecahan masalah, 6) mengamati benda dan gejala dengan rasa ingin tahu, 5) mengenal pola kegiatan dan menyadari pentingnya waktu, 8) memahami posisi/kedudukan dalam keluarga, ruang, lingkungan sosial. Melihat standar kemampuan problem solving di atas, maka seharusnya anak usia 4-5 seharusnya sudah mencapai standar tersebut.

Berdasarkan indikator di atas, guru dapat mengembangkan kemampuan problem solving melalui proses pembelajaran yang ideal untuk mengembangkan kemampuan problem solving pada anak usia dini dengan menggunakan media pembelajaran yang bervariasi serta kegiatan yang menarik sehingga anak mau terlibat aktif dalam proses pembelajaran. Guru mempunyai peranan penting dalam meningkatkan kemampuan problem solving pada anak usia dini. Ketika guru mengungkapkan masalah, mereka hendaknya menghadapkan masalah tersebut kepada anak dan mendiskusikan pemecahannya sehingga anak pun menyadari pentingnya proses pemecahan masalah. Dengan adanya media pembelajaran proses kegiatan belajar mengajar akan semakin dirasakan manfaatnya. Penggunaan media diharapkan akan menumbuhkan dampak posiif seperti munculnya proses pembelajaran yang lebih kondusif. Terjadinya umpan balik dalam proses belajar mengajar, dan mencapai hasil yang optimal. Dalam membantu anak untuk mengoptimalkan kemampuan memecahkan masalah, diperlukan guru sebagai fasilitator yang dapat memilih media pembelajaran yang membantu tercapainya tujuan pembelajaran. Pemilihan media pembelajaran yang sesuai merupakan bagian dari tercapainya proses kegiatan belajar mengajar yang efektif, kreatif, dan inovatif, serta menarik bagi anak sehingga diharapkan anak tertarik untuk mengikuti kegiatan belajar dan mengajar.

Penelitian mengenai media pembelajaran pernah dilakukan oleh Pambudi (2017) dengan judul Pengaruh Media Audio Visual Terhadap Perkembangan Kognitif Anak Kelompok B di TK Pertiwi Jenggrik II Sragen Tahun 2016/2017 dengan hasil penelitian yang cukup baik yaitu terdapat pengaruh media audio visual terhadap perkembangan kognitif anak. Menurut Sari, dkk (2018) dalam penelitian yang berjudul Penggunaan Media Puzzle Terhadap Kemampuan Pemecahan Masalah Anak Usia 5-6 Tahun juga menunjukkan hasil yang baik dengan adanya pengaruh media puzzle terhadap kemampuan pemecahan masalah anak dalam aspek menjumlahkan, mengelompokkan, dan membedakan bentuk. Menurut Jayadiningrat, Made Gautama (2018) bahwa penerapan Problem Based Learning dapat meningkatkan keterampilan memecahkan masalah.

Penelitian diatas menunjukkan bahwa meningkatkan kemampuan kognitif anak dapat dilakukan dengan menggunakan media pembelajaran yang sesuai dan efektif. Peneliti memilih menggunakan media pembelajaran busy book dengan mempertimbangkan kegiatan pembelajaran yang sesuai agar dapat mengembangkan kemampuan problem solving anak secara optimal. Kenyataan di lapangan menunjukkan bahwa masih jarang anak yang mampu memecahkan masalah sendiri. Hal ini terlihat ketika guru memberikan tugas kepada anak tetapi anak mengalami kesulitan dalam menyelesaikan tugasnya sendiri. Dalam proses pembelajaran, guru kurang mengembangkan media pembelajaran agar lebih bervariatif. 
Kemampuan pemecahan masalah anak hanya dikembangkan menggunakan media puzzle, playdough, dan media balok. Sehingga media yang terbatas tersebut membuat anak kurang terstimulus untuk dapat memecahkan masalah pada saat proses pembelajaran.

Melalui penggunaan media pembelajaran akan memudahkan guru dalam menyampaikan tujuan pembelajaran. Anak akan lebih tertarik dan terstimulus untuk dapat memecahkan masalah sendiri saat proses pembelajaran. Proses pembelajaran akan terasa menyenangkan ketika guru memberikan media pembelajaran yang sesuai dengan tema pembelajaran. Media pembelajaran yang tepat digunakan akan memberikan pengalaman belajar dan anak akan terlatih untuk dapat memecahkan masalah sendiri.

Salah satu solusi yang akan dilakukan oleh penulis adalah dengan menggunakan media busy book untuk dijadikan sebagai media mengembangkan kemampuan problem solving. Busy book adalah sebuah media pembelajaran yang interaktif. Penelitian mengenai pengembangan media busy book pernah dilakukan oleh Amaris, dkk (2018) dengan judul "Pengaruh Media Busy Book Terhadap Kemampuan Berhitung Anak Usia Dini di TK Fadhilah Amal 3 Padang" menunjukkan bahwa media pembelajaran busy book sangat berpengaruh meningkatkan kemampuan berhitung anak. Penelitian lain terkait penggunaan media busy book juga pernah dilakukan oleh Nurlaela (2018) dengan judul "Pengembangan Media Busy Book dalam Meningkatkan Kemampuan Bahasa Anak Usia Dini di Play Group Islam Bina Balita Lampung" menunjukkan bahwa media busy book sangat layak digunakan untuk meningkatkan kemampuan anak dan meningkatkan respon yang sangat baik dari anak.

Menurut Mufliharsi (2017), Pembelajaran menggunakan busy book memiliki beberapa keunggulan yakni : 1) Guru mudah menentukan materi ajar, hanya perlu disesuaikan antara konten dengan perintah, 2) guru dapat dengan mudah mengevaluasi siswa karena dengan sendirinya aktivitas yang terdapat di dalam buku dapat mengeksplorasi kemampuan masingmasing anak, 3) Anak tanpa diminta dapat langsung melakukan aktivitas yang ditutunt dalam setiap lembar busy book, 4) akan timbul rasa ingin tahu anak dan cenderung melakukan sendiri tanpa bantuan dari guru, 5) sifat media yang tahan lama karena terbuat dari kain sehingga tidak mudah kotor maupun robek, 6) Pembelajaran di kelas menjadi menyenangkan dan aktif, 7) pembelajaran menjadi menyenangkan karena banyak aktivitas, dan memancing kreativitas anak untuk melakukan aktivitas yang ada menjadi lebih baik dan sistematis.

Berdasarkan uraian di atas, tentang metode bermain menggunakan media busy book diharapkan mempunyai pengaruh terhadap kemampuan problem solving, untuk itu peneliti melakukan penelitian eksperimen dengan judul : "Pengaruh Media Busy Book Terhadap Kemampuan Problem Solving Pada Anak Kelompok A Taman Kanak-kanak Gugus VII Kecamatan Buleleng Tahun Pelajaran 2018/2019".

Adapun rumusan masalah dalam penelitian ini yaitu apakah terdapat perbedaan yang signifikan kemampuan problem solving antara anak yang dibelajarkan menggunakan media busy book dengan anak yang dibelajarkan menggunakan metode konvensional anak kelompok A Taman Kanak-kanak Gugus VII Kecamatan Buleleng tahun pelajaran 201/2019?. Tujuan penelitian ini adalah untuk mengetahui perbedaan yang signifikan kemampuan problem solving antara anak yang dibelajarkan menggunakan media busy book dengan anak yang dibelajarkan menggunakan metode konvensional anak kelompok A Taman Kanak-kanak Gugus VII Kecamatan Buleleng tahun pelajaran 2018/2019.

\section{Metode}

Penelitian ini dilaksanakan di Taman Kanak-kanak Gugus VII Kecamatan Buleleng yang terdiri dari 6 sekolah. Populasi yang digunakan pada penelitian ini adalah seluruh anak Taman Kanak-kanak Gugus VII Kecamatan Buleleng yang berjumlah 157 anak. Penelitian ini termasuk penelitian eksperimen semu (quasi eksperimen) dengan rancangan Non-equivalen Post Test Only Control Group Design. Pemberian treatment berupa perlakuan penggunaan media busy book terhadap kemampuan problem solving di kelompok eksperimen, sedangkan di kelompok kontrol dilakukan kegiatan yang tidak menggunakan media busy book dalam mengembangkan kemampuan problem solving. Post test dilakukan pada akhir penelitian setelah diberikan 
perlakuan untuk mendapatkan hasil perkembangan kemampuan problem solving di kelompok eksperimen dan kelompok kontrol yang bertujuan untuk mengetahui perkembangan kemampuan problem solving anak. Rancangan ini disajikan dalam Tabel 1.

Tabel 1. Rancangan Penelitian

\begin{tabular}{lcc}
\hline \multicolumn{1}{c}{ Kelas } & Perlakuan & Post-test \\
\hline Eksperimen & $\mathrm{X}$ & $\mathrm{O}_{1}$ \\
Kontrol & - & $\mathrm{O}_{2}$ \\
\hline
\end{tabular}

Teknik pengambilan sampel pada penelitian ini menggunakan teknik simple random sampling. Dari pengambilan sampel selanjutnya ditetapkan 2 sampel penelitian yaitu A1 TK Santa Maria yang berjumlah 20 orang anak sebagai kelompok eksperimen dan kelompok A1 TK Lab Undiksha yang berjumlah 17 orang anak sebagai kelompok kontrol.

Penelitian ini untuk mengetahui pengaruh satu variabel bebas dan variabel terikat. Variabel bebas dalam penelitian ini adalah media busy book dan variabel terikat kemampuan problem solving anak. Metode pengumpulan data yang dilakukan dalam penelitian ini menggunakan metode observasi. Uji coba instrumen pada penelitian ini menggunakan uji validitas isi. Uji validitas isi menggunakan rumus gregory, uji validitas empiris menggunakan rumus matriks tabulasi silang. Dalam menganalisis data menggunakan metode analisis statistik deskriptif yang bertujuan untuk mengetahui tinggi rendahnya data. Setelah dilakukan analisis statistik diskriptif selanjutnya akan dilakukan uji asumsi data yang terdiri dari uji normalitas menggunakan chi-square dan uji homogenitas menggunakan uji Fisher $(F)$. Uji hipotesis pada penelitian ini menggunakan uji-t sampel tidak berkolerasi dengan menggunakan rumus polled varians.

\section{Hasil dan Pembahasan}

Berdasarkan analisis data yang dilakukan terhadap kemampuan problem solving anak, diperoleh hasil seperti yang disajikan pada Tabel 2.

Tabel 2. Rekapitulasi Hasil Perhitungan Skor Kemampuan Problem Solving

\begin{tabular}{lcc}
\hline \multicolumn{1}{c}{ Statistik Deskriftif } & Kelompok Eksperimen & Kelompok Kontrol \\
\hline Mean & 48,55 & 34,18 \\
Median & 49 & 34 \\
Modus & 49 & 36 \\
Standar Deviasi & 2,781 & 2,698 \\
Varians & 7,734 & 7,279 \\
\hline
\end{tabular}

Berdasarkan tabel 2, rata-rata nilai akhir kemampuan problem solving anak untuk kelompok eksperimen yang dibelajarkan menggunakan media pembelajaran busy book adalah 48,55 dengan varians sebesar 7,734, modus 49, median 49,00 dan standar deviasi 2,781. Sedangkan rata-rata nilai akhir kemampuan problem solving anak pada kelompok kontrol yang dibelajarkan melalui metode konvensional adalah 34,18 dengan varians sebesar 7,279, modus 36, median 34,00 dan standar deviasi 2,698.

Data tersebut menunjukkan bahwa kemampuan problem solving anak kelompok eksperimen yang dibelajarkan menggunakan media pembelajaran busy book memiliki rata-rata lebih tinggi daripada kelompok kontrol yang dibelajarkan melalui metode konvensional. Setelah mengetahui mean, median, modus, maka sebaran data akan disajikan dalam grafik seperti Gambar 1 berikut. 


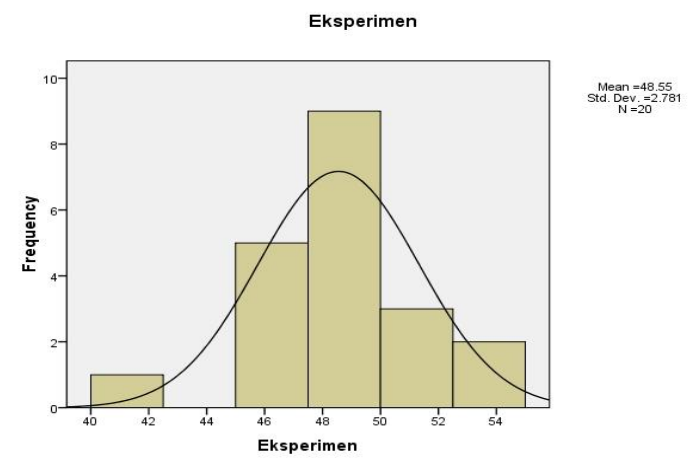

Gambar 1 Grafik sebaran data Kelompok Eksperimen

Gambar grafik di atas menunjukkan harga statistic Mo>Me>M. berdasarkan gambar tersebut dapat diinterpretasikan bahwa skor kemampuan problem solving anak cenderung tinggi. Selanjutnya data kelompok kontrol akan disajikan dalam grafik seperti gambar 2 berikut.

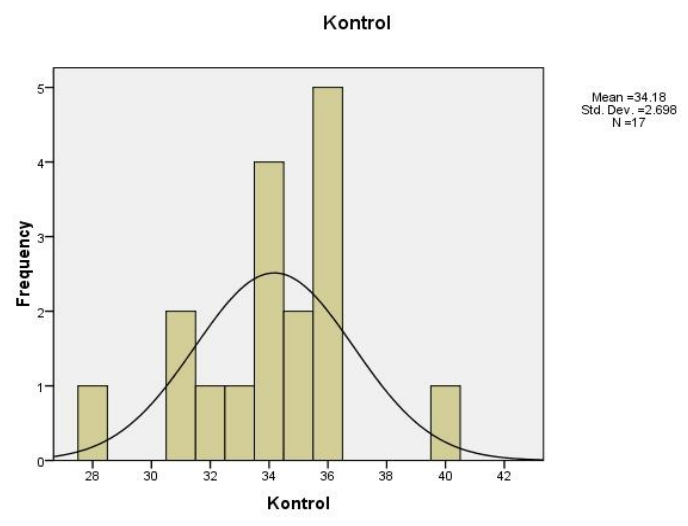

Gambar 2 Grafik sebaran data kelompok kontrol.

Gambar di atas menunjukkan bahwa $\mathrm{Mo}<\mathrm{Me}<\mathrm{M}$. Berdasarkan gambar tersebut dapat diinterpretasikan bahwa skor kemampuan problem solving anak cenderung rendah.

Selanjutnya untuk mengetahui perbedaan kepercayaan diri anak melalui pengujian hipotesis, terlebih dahulu dilakukan uji prasyarat analisis yaitu uji normalitas dan uji homogenitas. Ringkasan hasil uji normalitas kepercayaan diri anak dapat dilihat pada tabel 3

Tabel 3. Rangkuman Hasil Perhitungan

\begin{tabular}{clcccc}
\hline No & Kelompok Data & $\mathbf{N}$ & $\mathbf{X}^{2}$ hitung & $\mathbf{X}_{\text {tabel }}$ & Status \\
\hline 1 & Eksperimen & 20 & 11,20 & 14,017 & Normal \\
2 & Kontrol & 17 & 7,941 & 14,017 & Normal \\
\hline
\end{tabular}

Berdasarkan nilai $\mathrm{x}^{2}$ tabel pada taraf signifikansi $5 \%$ dan derajat kebebasan 7 adalah 14,017 dan hasil analisis Chi-square $=11,20$, sehingga $x^{2}$ hitung $<x^{2}$ tabel maka data berdistirbusi normal. Hal ini berarti sebaran data kemampuan problem solving anak pada kelas yang dibelajarkan menggunakan media pembelajaran busy book berdistribusi normal. 
Berdasarkan nilai $x^{2}$ tabel pada taraf signifikansi $5 \%$ dan derajat kebebasan 7 adalah 14,017 dan hasil analisis Chi-square $=7,941$, sehingga $x^{2}$ hitung $<x^{2}$ tabel maka data berdistirbusi normal. Hal ini berarti sebaran data kemampuan problem solving anak pada kelas yang dibelajarkan menggunakan metode konvensional berdistribusi normal.

Selanjutnya akan dilanjutkan dengan uji homogenitas varians. Uji homogenitas varians dapat dilihat pada Tabel 4

Tabel 4. Rangkuman Hasil Uji Homogenitas Varians

\begin{tabular}{|c|c|c|c|c|}
\hline Sampel & Varians & $F_{\text {hitung }}$ & $F_{\text {tabel }}(5 \%)$ & Status \\
\hline Eksperimen & 7,734 & 106 & 228 & Homogen \\
\hline Kontrol & 7,279 & & & \\
\hline
\end{tabular}

Berdasarkan Tabel 4, hasil uji homogenitas varians menunjukkan bahwa $F_{\text {hitung }}<F_{\text {tabel. }}$ Ini berarti bahwa varians antara kelompok eksperimen dan kelompok kontrol adalah homogen.

Setelah semua pengujian asumsi dilaksanakan, selanjutnya dilakukan pengujian hipotesis dengan uji-t. Uji hipotesis dilakukan untuk menguji hipotesis penelitian yang diajukan. Hipotesis nol $\left(\mathrm{H}_{0}\right)$ menyatakan bahwa tidak terdapat perbedaan yang signifikan kemampuan problem solving antara anak yang dibelajarkan dengan menggunakan media pembelajaran busy book dengan anak yang dibelajarkan menggunakan metode pembelajaran konvensional pada anak kelompok A di Taman Kanak-kanak Gugus VII Tahun Pelajaran 2018/2019. Sedangkan hipotesis alternatif $\left(\mathrm{H}_{\mathrm{a}}\right)$ menyatakan bahwa terdapat perbedaan yang signifikan kemampuan problem solving antara anak yang dibelajarkan meggunakan media pembelajaran busy book dengan anak yang dibelajarkan melalui metode pembelajaran konvensional pada anak kelompok A di Taman Kanak-kanak Gugus VII Kecamatan Buleleng Tahun Pelajaran 2018/2019.

Hipotesis yang diajukan diuji menggunakan uji-t. Uji-t adalah teknik statistik parametrik yang digunakan untuk membandingkan membandingkan 1 variabel bebas dan 1 variabel terikat. Hasil uji prasyarat yang telah dilaksanakan menunjukkan bahwa uji hipotesis dengan uji-t dapat dilakukan karena data telah berdistribusi normal dan homogen. Uji hipotesis dilakukan pada taraf signifikansi $5 \%$ dengankaidah hipotesis $\mathrm{H}_{0}$ ditolak jika $t_{\text {hitung }}>\mathrm{t}_{\text {tabel. }}$. Dan $\mathrm{H}_{0}$ diterima jika $t_{\text {hitung }}<t_{\text {tabel. }}$.

Berdasarkan hasil analisis uji-t dari data kemampuan problem solving anak diperoleh hasil sebagai berikut

Tabel 5. Rangkuman Hasil Uji Hipotesis

\begin{tabular}{cccccccc}
\hline Kelompok & $\mathbf{N}$ & $\mathbf{D k}$ & $\mathbf{M}$ & Varians & $\mathbf{t}_{\text {hitung }}$ & $\mathbf{t}_{\text {tabel }}$ & Keterangan \\
\hline Eksperimen & 20 & \multirow{2}{*}{35} & 48,55 & 7,734 & \multirow{2}{*}{15,882} & 2,03 & $\begin{array}{c}\mathrm{H}_{1} \text { Diterima } \\
\text { dan } \mathrm{H}_{0} \\
\text { Kontrol }\end{array}$ \\
\hline 17 & & 34,18 & 7,279 & & & Ditolak \\
\hline
\end{tabular}

Dari hasil analisis diperoleh $\mathrm{t}_{\text {hitung }}=15,882$. Harga tersebut kemudian dibandingkan dengan harga $t_{\text {tabel }}$ dengan $\mathrm{dk}=20+17-2=35$ dan taraf signifikansi $5 \%$ sehingga diperoleh harga $t_{\text {tabel }}=2,030$, karena $t_{\text {hitung }}=15,882>t_{\text {tabel }}=2,030$ maka $\mathrm{H}_{0}$ ditolak atau $\mathrm{H}_{\mathrm{a}}$ diterima. Hal ini berarti terdapat perbedaan yang signifikan kemampuan problem solving antara kelompok anak yang dibelajarkan menggunakan media pembelajaran busy book dan kelompok anak yang dibelajarkan menggunakan metode konvensional pada anak kelompok A di Taman Kanak-kanak Gugus VII Kecamatan Buleleng Tahun Pelajaran 2018/2019.

Adanya perbedaan yang signifikan menunjukkan bahwa media pembelajaran busy book berpengaruh terhadap kemampuan problem solving pada anak. Perbedaan antara pembelajaran menggunakan media pembelajaran busy book dengan pembelajaran menggunakan metode konvensional dapat dilihat dari perbedaan hasil analisis statistik 
deskripstif antara kedua kelompok sampel. Secara deskriptif rerata kemampuan problem solving anak kelompok eksperimen lebih tinggi yaitu sebesar 48,55 dibandingkan dengan rerata kemampuan problem solving kelompok kontrol sebesar 34,18.

Adanya perbedaan yang signifikan menunjukkan bahwa penggunaan media busy book lebih berpengaruh terhadap kemampuan problem solving dibandingkan dengan metode pembelajaran konvensional karena penggunaan media busy book membuat anak aktif untuk memecahkan masalah pada aktivitas-aktivtas yang ada pada setiap halaman busy book. Penggunaan media pembelajaran busy book juga memberikan suasana belajar menjadi lebih menarik dan interaktif, hal ini sesuai dengan teori yang dikatakan oleh Hamalik (2005: 26) adalah memperlancar interaksi antara guru dengan anak sehingga kegiatan pembelajaran lebih efektif, efisien dan menarik. Media pembelajaran banyak memberikan dampak positif bagi anak, sebagaimana Kemp \& Dayton dalam Azhar (2014: 25) mengemukakan bahwa media pembelajaran dapat membuat pembelajaran lebih menarik, efisien, dapat menimbulkan sikap positif anak terhadap suatu pembelajaran dan sebagai alat yang membantu meningkatkan kemampuan anak agar kemampuan anak dapat berkembang secara optimal.

Pembelajaran menggunakan media busy book yang diterapkan pada kelompok eksperimen memiliki banyak keunggulan dibandingkan dengan kelompok kontrol. Hal ini disebabkan karena media busy book lebih unggul penggunaannya karena mampu meningkatkan kemampuan kognitif berpikir anak dalam hal mengenal menyelesaikan masalah baik memberikan penyelesaian masalah yang berbeda pada satu objek masalah yang masalah maupun mampu menyelesaikan masalah yang berbeda pada setiap objek sehingga anak tidak cepat merasa bosan dan selalu belajar yang baru dibandingkan dengan pembelajaran konvensional yang hanya berpusat pada guru dan hanya menggunakan metode ceramah dalam menyampaikan suatu materi pada anak.

Temuan pada penelitian ini memiliki persamaan dengan penelitian sebelumnya yang relevan dan memperkuat hasil penelitian yang diperoleh. Hal tersebut didukung hasil penelitian yang dilakukan oleh Rilasya (2016), hasil penelitian menunjukkan bahwa melalui problem solving dengan benda konkret dapat meningkatkan kemampuan penjumlahan pada anak usia kelompok B. Penelitian ini juga diperkuat dengan dukungan teori dari Rita (2014) media pembelajaran adalah segala alat komunikatif yang dapat digunakan untuk menyampaikan pesan atau informasi dari sumber kepada peserta didik yang bertujuan agar dapat merangsang pikiran, perasaan, minat dan perhatian peserta didik untuk mengikuti kegiatan pembelajaran.

Berdasarkan paparan tersebut, dapat disimpulkan bahwa media pembelajaran busy book berpengaruh terhadap kemampuan problem solving pada anak kelompok A di Taman Kanak-kanak Gugus VII Kecamatan Buleleng Tahun Pelajaran 2018/2019.

\section{Simpulan dan Saran}

Berdasarkan pemaparan dan pembahasan hasil penelitian, maka dapat disimpulkan bahwa terdapat perbedaan yang signifikan kemampuan problem solving pada anak kelompok A Taman Kanak-kanak Gugus VII Kecamatan Buleleng Tahun Pelajaran 2018/2019. Hal ini tampak dari pengujian hasil hipotesis menggunakan uji-t diperoleh $t_{\text {hitung }}=15,882$ sedangkan pada taraf signifikansi $5 \%$ dan $\mathrm{dk}=35$ diperoleh nilai $t_{\text {tabel }}=2,030$ sehingga $t_{\text {hitung }}=15,882>$ $t_{\text {tabel }}=2,030$. Ini berarti terdapat perbedaan yang signifikan kemampuan problem solving pada anak kelompok A di TK Gugus VII Kecamatan Buleleng Tahun Pelajaran 2018/2019 yang mengikuti pembelajaran menggunakan media pembelajaran busy book dan anak yang mengikuti pembelajaran konvensional pada tema pembelajaran tanah airku. Rata-rata kemampuan problem solving kelompok eksperimen lebih tinggi dari kelompok kontrol yaitu $48,55>34,18$, sehingga dapat disimpulkan bahwa media pembelajaran busy book berpengaruh terhadap kemampuan problem solving anak.

Hasil penelitian ini digunakan sebagai bahan masukan bagi guru untuk memilih media pembelajaran yang bervariasi dan menyenangkan dalam mengajar. Salah satunya adalah dengan menerapkan pembelajaran menggunakan media pembelajaran busy book. Media busy book memiliki banyak aktivitas untuk merangsang cara berfikir anak untuk dapat mencari jalan 
keluar atau cara penyelesaian dari setiap akivitas yang berbeda sehingga dapat digunakan untuk meningkatkan kemampuan problem solving anak. Hal tersebut dapat dilihat dari rata-rata perolehan nilai anak setelah dibelajarkan menggunakan media busy book sehingga dapat diambil kesimpulan bahwa penggunaan media busy book dapat memberikan pengaruh positif terhadap hasil belajar kemampuan problem solving anak.

Media busy book dapat membantu guru dan membuat guru juga ikut berantusias dalam menyampaikan suatu informasi atau materi pembelajaran karena terdapat timbal balik yang positif dari anak. Pada akhirnya hasil belajar anak dalam meningkatkan kemampuan problem solving dapat tercapai secara maksimal. Bagi peneliti, yang berminat untuk mengadakan penelitian lebih lanjut tentang media busy book dalam menstimulasi kemampuan problem solving anak agar memperhatikan kekurangan dalam penelitian ini sebagai bahan pertimbangan untuk perbaikan dan penyempurnaan penelitian yang dilaksanakan.

\section{Daftar Pustaka}

Agung, A.A. 2016. Statistik Dasar untuk Pendidikan. Yogyakarta: Deepublish.

Jayadiningrat, Made Gautama, and Emirensia K. Ati. "Peningkatan Keterampilan Memecahkan Masalah Melalui Model Pembelajaran Problem Based Learning (PBL) pada Mata Pelajaran Kimia." Jurnal Pendidikan Kimia Indonesia 2.1 (2018): 1-7.

Kariadnyani, Kadek. Era. 2016. Pengaruh Model Course Review Horay Berbantuan Multimedia Terhadap Hasil Belajar IPA Siswa Kelas V SD. E-Journal PGSD Universitas Pendidikan Ganesha Jurusan PGSD, Vol. 4, No. 1.

Kurniasih, Sani. 2015. Ragam Pengembangan Model Pembelajaran Untuk Peningkatan Profesional Guru. Jakarta: Kata pena.

Lapatta, Jusman. 2015. Peningkatan Hasil Belajar Siswa Melalui Penggunaan Model Pembelajaran Course Review Horay Pada Mata Pelajaran IPA Kelas IV SD Inpres Sintuwu. Jurnal Kreatif Tadulako Online, Vol. 5, No.8.

Permendiknas Nomor 24 Tahun 2006 tentang Pelaksanaan Peraturan Menteri Pendidikan Nasional Nomor 22 Tahun 2006 dan Peraturan Menteri Pendidikan Nasional Nomor 23 Tahun 2006.

Santoso, Budi. 2013. Skema dan mekanisme pelatihan Panduan Penyelanggaraan pelatihan. Jakarta: Terang.

Siska. 2016. Konsep Dasar IPS. Yogyakarta. Garudhawaca.

Shoimin, Aris. 2014. 68 Model Pembelajaran Inovatif dalam Kurikulum 2013. Yogyakarta: Pustaka Belajar.

Sriwati,Ni. Luh. Gede. 2014. Penerapan Model Pembelajaran Course Review Horay Bebantuan Media Gambar Untuk Meningkatkan Kemampuan Bahasa Anak. e-Journal PG-PAUD Universitas Pendidikan Ganesha Jurusan Pendidikan Guru Pendidikan Anak Usia Dini, Vol. 2, No. 1.

Welle,Deutsche. 2017. Rangking Pendidikan Negara-Negara Asean. http://www.dw.com/id/rangking-pendidikan-negara-negara-asean/g-37594464/ Desember 2017). 